Proceedings of the XXIII Conference on Applied Crystallography, Krynica Zdrój, Poland, September 20-24, 2015

\title{
XRD and TEM in situ Heating of Large Period Ni/Al Multilayer Coatings
}

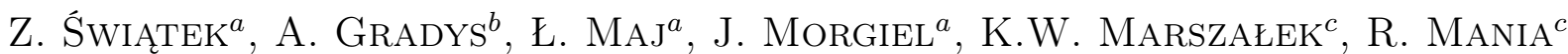 \\ AND M. SZLEZYNGER ${ }^{a}$ \\ ${ }^{a}$ Institute of Metallurgy and Materials Science, PAS, W. Reymonta 25, 30-059 Cracow, Poland \\ ${ }^{b}$ Institute of Fundamental Technological Research, PAS, Warsaw, Poland \\ ${ }^{c}$ AGH University of Science and Technology, Cracow, Poland
}

\begin{abstract}
The $\mathrm{Ni} / \mathrm{Al}$ multilayer coating of $\lambda \approx 100 \mathrm{~nm}$ was deposited onto (001)-oriented monocrystalline silicon substrate using double target magnetron sputtering system equipped with rotating sample holder. The thicknesses of alternating layers were adjusted in the way to preserve the chemical composition ratio close to $50 \% \mathrm{Al}: 50 \% \mathrm{Ni}$ (at.\%). The in situ X-ray diffraction and in situ transmission electron microscopy heating experiments were carried out at relatively low heating rates $\left(20^{\circ} \mathrm{C} / \mathrm{min}\right)$ in order to study the phase transformation sequence. The investigations revealed that the reaction between $\mathrm{Ni}$ and $\mathrm{Al}$ multilayers starts at $\approx 200^{\circ} \mathrm{C}$ with precipitation of $\mathrm{Al}_{3} \mathrm{Ni}$ phase, while above $300^{\circ} \mathrm{C}$ dominates precipitation of $\mathrm{Ni}_{3} \mathrm{Al}$ and $\mathrm{NiAl}$ intermetallic phases. Both the $\mathrm{X}$-ray and electron diffractions acquired at $450{ }^{\circ} \mathrm{C}$ confirmed presence of the $\mathrm{Ni}_{3} \mathrm{Al}$ and $\mathrm{NiAl}$ intermetallics, but the former pointed at still lasting traces of $\mathrm{Ni}(\mathrm{Al})$ solid solution.
\end{abstract}

DOI: 10.12693/APhysPolA.130.880

PACS/topics: 68.65.Ac, 68.37.Lp

\section{Introduction}

Reactive metallic multilayers (RMM) like $\mathrm{Ni} / \mathrm{Al}$, $\mathrm{Ti} / \mathrm{Al}$, or $\mathrm{Ni} / \mathrm{Ti}$ could be applied for relatively low temperature synthesis of intermetallic compounds. The selfpropagating high-temperature synthesis (SHS) nature of RMM reactions was already commercialized for joining of heat sensitive materials with $\mathrm{Ni} / \mathrm{Al}$ free-standing foils (NanoFoil ${ }^{\circledR}$ ).

The sequence of phase transformation during heating of RMM was extensively studied with differential scanning calorimetry (DSC) and X-ray diffraction (XRD) especially widely for $\mathrm{Ni} / \mathrm{Al}[1-7]$. They showed that reaction of low period multilayer, i.e. those with multilayer period $\lambda<50 \mathrm{~nm}$, directly leads to formation of intermetallic phase like $\mathrm{NiAl}_{3}[6]$ or $\mathrm{NiAl}[3,5]$. The same heat treatment applied to large period $(\lambda \approx 100 \mathrm{~nm})$ $\mathrm{Ni} / \mathrm{Al}$ multilayers of the same $\mathrm{Ni}: \mathrm{Al}$ ratio resulted in formation of $\mathrm{Ni}_{2} \mathrm{Al}_{9}$ intermediate phase [8]. However, due to very fine size of crystallites of phases nucleating and growing during such reactions, as well as usually RMM small overall thickness, the measurements using X-ray diffraction are far from decisive.

The transmission electron microscopy (TEM) method was already used for analysis of the phase transformations taking place during heating of the RMM, but it was limited to pin pointing of nucleation places and elucidating the growth mechanism of newly formed phases in $\mathrm{Ni} / \mathrm{Al}$ with 3:1 ratio of $\mathrm{Ni}$ to $\mathrm{Al}$ leading to precipitation of $\mathrm{Ni}_{2} \mathrm{Al}_{9}$ [2]. Our own in situ TEM experiments including phase analysis relying on selected area electron diffraction (SAED) technique performed on large period $\mathrm{Ni} / \mathrm{Al}$ multilayers with 1:1 Ni to $\mathrm{Al}$ ratio, i.e. of composition close to $\mathrm{NiAl}$ final product, also indicated that precipitation of an intermediate $\mathrm{Ni}_{2} \mathrm{Al}_{9}$ phase in such case is involved [8].
The XRD phase analysis lack of sensitivity concerning nanocrystalline material is easily made over by TEM well recognized for its ultimate spatial resolution. However, the latter is weighted by artifacts resulting either from preparation of thin foils or formed during in situ heating. Therefore, the present work was aimed at following the phase transformations taking place during in situ XRD and TEM heating of large period $\mathrm{Ni} / \mathrm{Al}$ multilayers.

\section{Experimental methods}

The $\mathrm{Ni} / \mathrm{Al}$ multilayers with $\lambda \approx 100 \mathrm{~nm}$ were deposited using double target magnetron sputtering system equipped with rotating substrate holder. The special metallic shutters in glow discharge zones were applied aimed at separation of $\mathrm{Ni}$ and $\mathrm{Al}$ atoms streams [9]. The argon was introduced into the chamber $($ at $\approx$ $10^{-3}$ mbar) only after the pressure of $5 \times 10^{-5}$ mbar was attained. The multilayers were sputtered from pure $\mathrm{Ni}$ and $\mathrm{Al}$ targets onto monocrystalline silicon substrates.

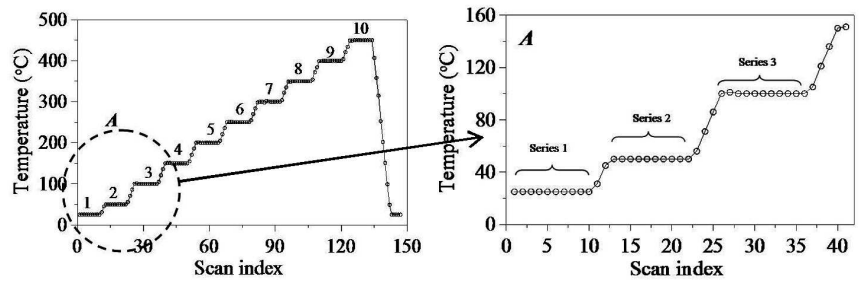

Fig. 1. Heating curve of $\mathrm{Ni} / \mathrm{Al}$ multilayers (left) and a cut-out presenting experimental details (right).

The XRD measurements were carried out using Bruker D8 Discover diffractometer $(40 \mathrm{kV} / 40 \mathrm{~mA})$ with $\mathrm{Cu}$ anode $(\lambda=1.5406 \AA)$. The measurements were performed in reflection mode (the Bragg-Brentano geometry) with 
the Goebel mirror with deflection $0.677^{\circ}$ and $1 \mathrm{~mm}$ slit and two Soller collimators of axial divergence $2.5^{\circ}$. The heating experiments were performed in temperature range from $25^{\circ} \mathrm{C}$ to $450^{\circ} \mathrm{C}$ using Anton-Paar TTK 450 chamber equipped with liquid nitrogen cooling system. The sample was subjected to heating to steps every $50^{\circ} \mathrm{C}$ up to $450^{\circ} \mathrm{C}$ at a rate of $20^{\circ} \mathrm{C} / \mathrm{min}$, followed by cooling to $25^{\circ} \mathrm{C}$ at a rate of $30^{\circ} \mathrm{C} / \mathrm{min}$ (see Fig. 1 ). The sample was scanned ten times at high sampling rate at particular temperature step, 0.045 second per point, with angular resolution $0.04^{\circ}$ in $2 \theta$ range $30-60^{\circ}$. Additional measurements at $25^{\circ} \mathrm{C}$ were performed before the in situ experiment in order to determine lattice parameters of initial phases. Structure refinement was performed using the whole-pattern decomposition (Profile Matching) procedure (also known as LeBail fitting [10]), as implemented in the FullProf program [11]. The lattice parameters were precisely determined by Dicvol04 program [12].

The in situ heating of $\mathrm{Ni} / \mathrm{Al}$ multilayers were carried out using FEI TECNAI SuperTWIN FEG (200 kV) microscope and Gatan heating holder. Thin foils for TEM were cut out using FEI Quanta 200 dual beam focused ion beam (FIB). The microstructure observations were performed in bright field $(\mathrm{BF})$ mode. The samples were subjected to heating at a rate of $20^{\circ} \mathrm{C} / \mathrm{min}$ up to $450{ }^{\circ} \mathrm{C}$. The temperature was maintained for $\approx 7$ min at sequence: $25,50,100,150,200,250,300,350$ and $450^{\circ} \mathrm{C}$ in order to acquire the $\mathrm{BF}$ images and selected area diffraction patterns (SADP) at each step. The indexing of electron diffractions was performed with the help of Janos Labar Process Diffraction shareware [13]. The diffraction data was analyzed using the crystallographic database PDF4 [14].

\section{Results and discussion}

The analysis of the X-ray diffraction pattern showed that the "as-deposited" $\mathrm{Ni} / \mathrm{Al}$ multilayers consisted of solid solution of $\mathrm{Ni}(\mathrm{Al})$ and $\mathrm{Al}(\mathrm{Ni})$. It revealed the presence of strong peak at $\approx 44^{\circ}$ corresponding to the (111) $\mathrm{Ni}(\mathrm{Al})$ phase and two smaller peaks of (111) $\mathrm{Al}(\mathrm{Ni})$ and $(200) \mathrm{Ni}(\mathrm{Al})$. The estimated unit cell parameters were of $a=(0.35281 \pm 0.00009) \mathrm{nm}$ and $a=(0.40365 \pm$ $0.00011) \mathrm{nm}$ for $\mathrm{Ni}(\approx 1.45 \mathrm{wt} \% \mathrm{Al})$ and $\mathrm{Al}(\approx 6.97 \mathrm{wt} \%$ $\mathrm{Ni}$ ), respectively. The small peaks at $\approx 35^{\circ}, \approx 42^{\circ}$ and $\approx 46^{\circ}$ corresponding to the orthorhombic phase of $\mathrm{Al}_{3} \mathrm{Ni}$ (Pnma(62), $a=0.659 \mathrm{~nm}, b=0.735 \mathrm{~nm}, c=0.480 \mathrm{~nm}$ ) were detected (Fig. 2a) already at $200^{\circ} \mathrm{C}$, providing an evidence of the beginning of multilayer reaction at so low temperature. The rise of the temperature up to $250{ }^{\circ} \mathrm{C}$ resulted in an increase of the contribution from the $\mathrm{Al}_{3} \mathrm{Ni}$ phase and complete disappearance of the $\mathrm{Al}(\mathrm{Ni})$. The crystallization of cubic NiAl $(P m-3 m(221)$, $a=0.288 \mathrm{~nm})$ final phase occurred after heating of the multilayer up to $300^{\circ} \mathrm{C}$. Still higher temperature $\left(350^{\circ} \mathrm{C}\right)$ causes not only a disappearance of $\mathrm{Al}_{3} \mathrm{Ni}$ phase, but also the crystallization of cubic $\mathrm{Ni}_{3} \mathrm{Al}(\mathrm{Pm}-3 m(221)$, $a=0.3572 \mathrm{~nm}$ ) phase (Fig. $2 \mathrm{~b}$ ). The heating of the $\mathrm{Ni} / \mathrm{Al}$ multilayer up to $400^{\circ} \mathrm{C}$ continues the process of "substitution" of $\mathrm{NiAl}$ with $\mathrm{Ni}_{3} \mathrm{Al}$. It should be noted that the
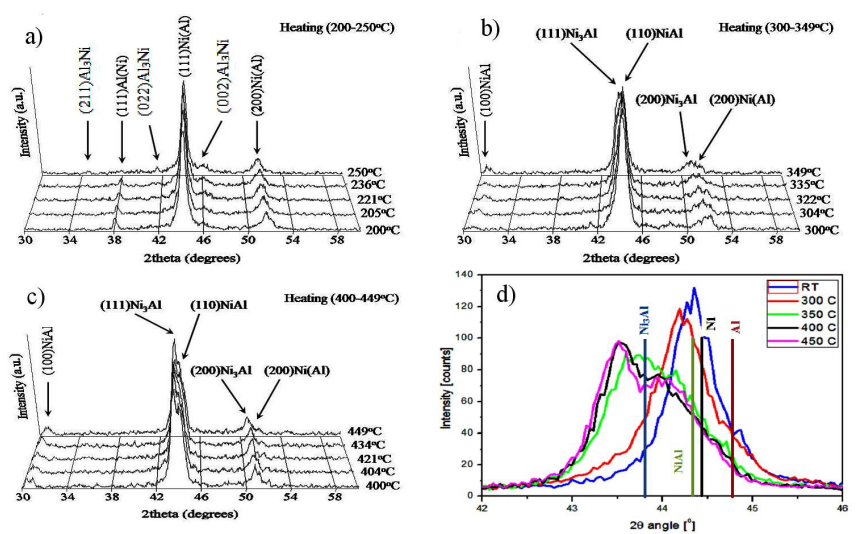

Fig. 2. X-ray diffraction patterns of $\mathrm{Ni} / \mathrm{Al}$ multilayer recorded during heating up to $250^{\circ} \mathrm{C}$ (a), $350^{\circ} \mathrm{C}$ (b), $450^{\circ} \mathrm{C}(\mathrm{c})$, comparative pattern for $2 \theta-\left(42^{\circ}-46^{\circ}\right)(\mathrm{d})$.

$\mathrm{Ni}(\mathrm{Al})$ solid solution is still present in a small amount up to $450^{\circ} \mathrm{C}$ (Fig. 2c). At that stage, the $\mathrm{Al} / \mathrm{Ni}$ multilayer also consists of two intermetallic phases, i.e. cubic $\mathrm{NiAl}$ and cubic $\mathrm{Ni}_{3} \mathrm{Al}$. The hot-stage XRD experiments carried out by Ramos et al. [3, 5] showed that in the case of $\mathrm{Al} / \mathrm{Ni}$ multilayers with similar bi-layer thickness $(\lambda=140 \mathrm{~nm})$, the formation of $\mathrm{NiAl}$ is preceded by nucleation of $\mathrm{Ni}_{2} \mathrm{Al}_{3}$ intermediate phase, coexisting in initial stage with $\mathrm{Al}_{3} \mathrm{Ni}$ one. The $\mathrm{Ni}_{2} \mathrm{Al}_{3}$ was the second phase to form between $250{ }^{\circ} \mathrm{C}$ and $425^{\circ} \mathrm{C}$. However, in case of experiments performed by Ramos et al. samples were heated with much higher rate of $60^{\circ} \mathrm{C} / \mathrm{min}$ and the acquisition time was faster than in present work (22 min per scan) which could affect the microstructural evolution. Based on phase analysis of heat treated $\mathrm{Al} / \mathrm{Ni}$ multilayers using XRD, the structural evolution can be presented as follows:

$$
\begin{aligned}
& \mathrm{Ni}(\mathrm{Al})+\mathrm{Al}(\mathrm{Ni}) \stackrel{200^{\circ} \mathrm{C}}{\Longrightarrow} \mathrm{Ni}(\mathrm{Al})+\mathrm{Al}(\mathrm{Ni})+\mathrm{Al}_{3} \mathrm{Ni} \stackrel{300^{\circ} \mathrm{C}}{\Longrightarrow} \\
& \mathrm{Ni}(\mathrm{Al})+\mathrm{NiAl} \stackrel{350^{\circ} \mathrm{C}}{\Longrightarrow} \mathrm{Ni}(\mathrm{Al})+\mathrm{Ni}_{3} \mathrm{Al}+\mathrm{NiAl} \stackrel{450^{\circ} \mathrm{C}}{\Longrightarrow} \\
& \mathrm{Ni}(\mathrm{Al})_{\text {traces }}+\mathrm{Ni}_{3} \mathrm{Al}+\mathrm{NiAl} .
\end{aligned}
$$

The microstructure observations of the "as-deposited" $\mathrm{Ni} / \mathrm{Al}$ multilayers revealed that they consist of fine grains of $\mathrm{Ni}$ and $\mathrm{Al}$ with the average size smaller than the thickness of individual layer (Fig. 3a). The bi-layer and overall thicknesses of the multilayers were $\approx 100 \mathrm{~nm}$ and $\approx 1600 \mathrm{~nm}$, respectively. The layer-to-layer thickness ratio was estimated at 1:1. The thickness of Al layer can be slightly underestimated due to the screening by $\mathrm{Ni}$ ones. Even as the interfacial roughness increases with the distance from the substrate, though the internal interfaces were still well defined. The SADP acquired from a coating section showed continuous rings of intensity corresponding to nanocrystalline multilayer microstructure. The integration of the intensities over the radii allowed to present the diffraction pattern in scattering vector space (also in Fig. 3a). As a result, aside of one strong peak a series of smaller peaks were also obtained. Checking the PDF4 database confirmed that the strongest one is 
formed by overlapping of (111) $\alpha$-Ni and (200) $\alpha$-Al peaks (weak peak in range from $\approx 151 / \mathrm{nm}$ up to $\approx 201 / \mathrm{nm}$ could be ascribed to presence of local oxides).
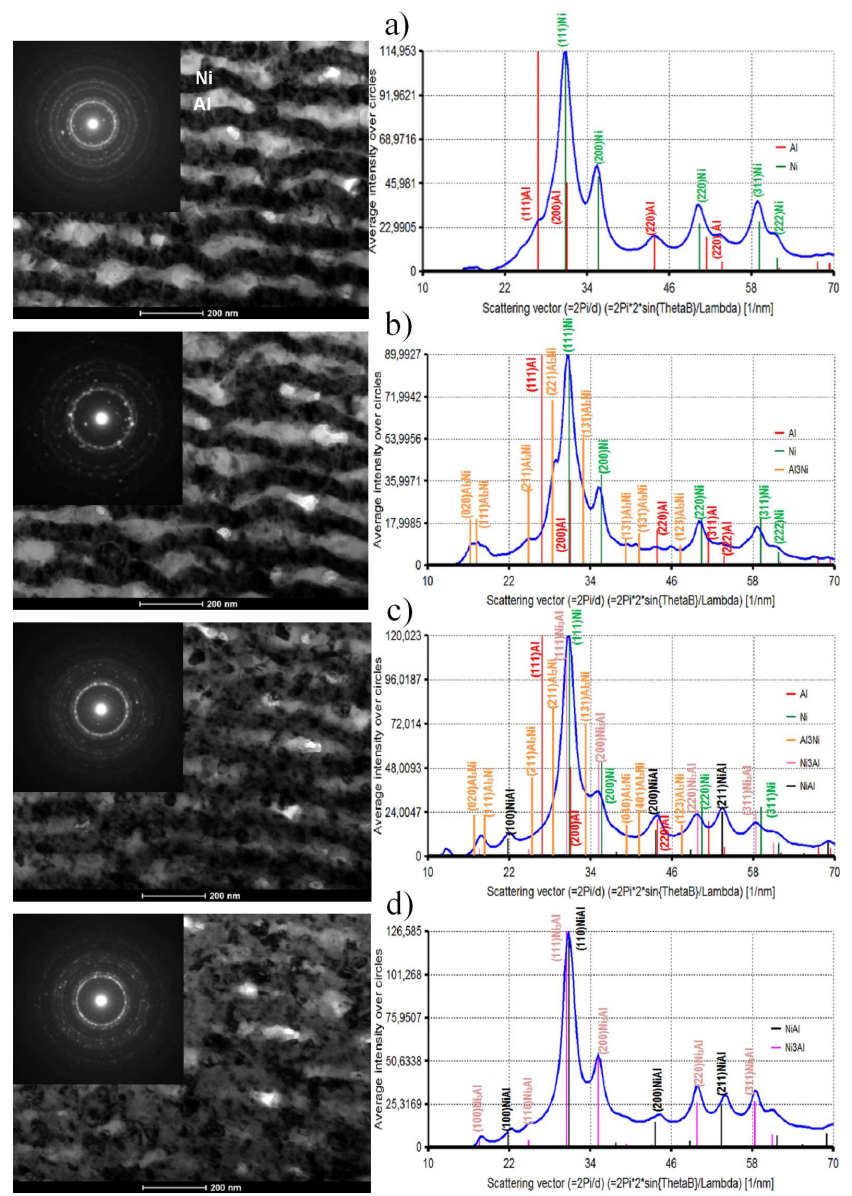

Fig. 3. TEM images, SAD patterns and integrated intensities of diffraction rings of: (a) "as-deposited" $\mathrm{Ni} / \mathrm{Al}$ multilayer and in situ heated to (b) $200^{\circ} \mathrm{C}$, (c) $350^{\circ} \mathrm{C}$, (d) $450{ }^{\circ} \mathrm{C}$.

The in situ TEM heating of $\mathrm{Ni} / \mathrm{Al}$ multilayers was performed in the way to follow procedure applied in case of in situ XRD experiment. The integrated intensities of electron diffraction rings helped to prove that first changes in phase content start indeed at $200-250^{\circ} \mathrm{C}$, and that the shifts in intensities (ring at $\approx 151 / \mathrm{nm}$ ) could be ascribed to formation of $\mathrm{Al}_{3} \mathrm{Ni}$ phase (Fig. 3b). The support of precipitation of new phase in investigated multilayer through microstructure observation was found only after attaining $300^{\circ} \mathrm{C}$, at which temperature chains of new nanocrystallites at internal $\mathrm{Ni} / \mathrm{Al}$ interfaces and growing into Al layers were clearly distinguished. Simultaneously, rings connected with $\mathrm{Al}_{3} \mathrm{Ni}$ phase started to sharpen and rise in intensity. It confirms that for large multilayer period and medium to low heating rates reaction is controlled by the rate at which the $\mathrm{Ni}$ atoms diffuse to $\mathrm{Al}_{3} \mathrm{Ni} / \mathrm{Al}$ growth front. Heating, up to still higher temperature $\left(350^{\circ} \mathrm{C}\right)$ results in growth of newly nucleated $\mathrm{Ni}_{3} \mathrm{Al}$ phase (Fig. 3c). Eventually, after reaching at
$400{ }^{\circ} \mathrm{C}$, all of the material of initial $\alpha-\mathrm{Al}$ and $\alpha-\mathrm{Ni}$ phases reacted to form intermetallic $\mathrm{Ni}_{3} \mathrm{Al}$ and $\mathrm{NiAl}$ phases. The temperature rise up to $450^{\circ} \mathrm{C}$ caused only an increase of $\mathrm{Ni}_{3} \mathrm{Al}$ phase as compared to that at $400^{\circ} \mathrm{C}$ (Fig. $3 \mathrm{~d}$ ). The results of analysis of the SADP acquired during heating of thin foil of $\mathrm{Ni} / \mathrm{Al}$ multilayer can be summarized as

$$
\begin{gathered}
\mathrm{Ni}+\mathrm{Al} \stackrel{200^{\circ} \mathrm{C}}{\Longrightarrow} \mathrm{Ni}+\mathrm{Al}+\mathrm{Al}_{3} \mathrm{Ni} \stackrel{350^{\circ} \mathrm{C}}{\Longrightarrow} \\
\mathrm{Ni}+\mathrm{Al}+\mathrm{Al}_{3} \mathrm{Ni}+\mathrm{Ni}_{3} \mathrm{Al}+\mathrm{NiAl} \stackrel{450^{\circ} \mathrm{C}}{\Longrightarrow} \mathrm{Ni}_{3} \mathrm{Al}+\mathrm{NiAl} .
\end{gathered}
$$

As the electron diffraction is less precise than the X-ray diffraction in determining the elementary unit cell of the respective phases, therefore in the former case the reference to a possible solid solution was skipped. Our previous experiments [8] with heating of $\mathrm{Ni} / \mathrm{Al}$ multilayers $(\lambda=100 \mathrm{~nm})$ with higher heating rates $\left(100^{\circ} \mathrm{C} / \mathrm{min}\right)$ showed that no reaction occurred up to $300^{\circ} \mathrm{C}$. The increase of temperature up to $350^{\circ} \mathrm{C}$ resulted in precipitation of metastable $\mathrm{Al}_{9} \mathrm{Ni}_{2}$ phase. It was the only intermediate phase preceding nucleation of $\mathrm{NiAl}$ final phase (at $500^{\circ} \mathrm{C}$ ), as compared to present work. The reason for such changes in-between these two otherwise very similar TEM in situ heatings could be ascribed only to the differences in applied heat treatment, as otherwise all experimental parameters were similar.

\section{Summary}

Performing in situ XRD and TEM heating of large period $(\lambda \approx 100 \mathrm{~nm}) \mathrm{Ni} / \mathrm{Al}$ multilayer at roughly the same conditions proved that as long as the applied timetemperature heat treatment path is close, than the sequences of phase transformation are also similar. An especially good agreement is achieved as it concerns the start of reaction and precipitation of the dominating phases, i.e.:

$$
\begin{aligned}
& \text { in situ } \mathrm{XRD} \Longrightarrow \mathrm{Ni}(\mathrm{Al})+\mathrm{Al}(\mathrm{Ni}) \stackrel{200^{\circ} \mathrm{C}}{\Longrightarrow} \\
& \mathrm{Ni}(\mathrm{Al})+\mathrm{Al}(\mathrm{Ni})+\mathrm{Al}_{3} \mathrm{Ni} \stackrel{300^{\circ} \mathrm{C}}{\Longrightarrow} \mathrm{Ni}(\mathrm{Al})+\mathrm{NiAl} \stackrel{350^{\circ} \mathrm{C}}{\Longrightarrow} \\
& \mathrm{Ni}(\mathrm{Al})+\mathrm{Ni}{ }_{3} \mathrm{Al}+\mathrm{NiAl} \stackrel{450^{\circ} \mathrm{C}}{\Longrightarrow} \mathrm{Ni}(\mathrm{Al})_{\text {traces }}+\mathrm{Ni}_{3} \mathrm{Al}+\mathrm{NiAl}, \\
& \quad \text { in situ } \mathrm{TEM} \Longrightarrow \mathrm{Ni}+\mathrm{Al} \stackrel{200^{\circ} \mathrm{C}}{\Longrightarrow} \mathrm{Ni}+\mathrm{Al}+\mathrm{Al}_{3} \mathrm{Ni} \stackrel{350^{\circ} \mathrm{C}}{\Longrightarrow} \\
& \mathrm{Ni}+\mathrm{Al}+\mathrm{Al}_{3} \mathrm{Ni}+\mathrm{Ni}_{3} \mathrm{Al}+\mathrm{NiAl} \stackrel{450^{\circ} \mathrm{C}}{\Longrightarrow} \mathrm{Ni}_{3} \mathrm{Al}+\mathrm{NiAl} .
\end{aligned}
$$

Only in case of intermediate temperatures, the TEM electron diffractions showed presence of aluminum and aluminum rich phases, i.e. $\mathrm{Al}$ and $\mathrm{Al}_{3} \mathrm{Ni}$ phase up to $350^{\circ} \mathrm{C}$, while at XRD spectra they were both extinguished at that temperature. On the other hand, the XRD showed small $\mathrm{Ni}(\mathrm{Al})$ contribution up to $450^{\circ} \mathrm{C}$, while the $\mathrm{Ni}$ phase was observed in TEM only up to $400^{\circ} \mathrm{C}$.

The differences in sequence of phase transformation observed between our previous [8] and present experiment indicate that the reaction path is especially sensitive - including formation of metastable phases like $\mathrm{Al}_{9} \mathrm{Ni}_{2}$ - to any changes in applied time-temperature heating scheme. 


\section{Acknowledgments}

The research was performed in a frame of the project no. DEC-2012/05/B/ST8/01794 supported by National Science Center (NCN) of Poland.

\section{References}

[1] A.S. Edelstein, R.K. Everett, G.Y. Richardson, S.B. Qadri, E.I. Altman, J.C. Folley, J.H. Perepezko, J. Appl. Phys. 76, 7850 (1994).

[2] K.J. Blobaum, D. Van Heerden, A.J. Gavens, T.P. Weihs, Acta Mater. 51, 3871 (2003).

[3] J. Noro, A.S. Ramos, M.T. Vieira, Intermetallics 16, 1061 (2008).

[4] A.J. Gavens, D. Van Heerden, A.B. Mann, M.E. Reiss, T.P. Weihs, J. Appl. Phys. 87, 1255 (2000).

[5] A.S. Ramos, M.T. Vieira, J. Morgiel, J. Grzonka, S. Simőes, M.F. Vieira, J. Alloys Comp. 484, 335 (2009).
[6] S. Simőes, F. Viana, A.S. Ramos, M.T. Vieira, M.F. Vieira, Intermetallics 19, 350 (2011).

[7] C. Michaelsen, K. Barmak, T.P. Weihs, J. Phys. D Appl. Phys. 30, 3167 (1997).

[8] J. Morgiel, M. Szlezynger, M. Pomorska, Ł. Maj, K. Marszałek, R. Mania, Int. J. Mater. Res. 106, 703 (2015).

[9] K. Marszałek, J. Stępień, R. Mania, Int. J. Electron. Telecom. 60, 291 (2014).

[10] A. LeBail, H. Duroy, J.L. Fourquet, Mater. Res. Bull. 23, 447 (1988).

[11] J. Rodriguez-Carvajal, Physica B 192, 55 (1993).

[12] A. Boultif, D. Louer, J. Appl. Crystallogr. 37, 724 (2004).

[13] J.L. Lábár, Ultramicroscopy 103, 237 (2005).

[14] Joint Committee on Powder Diffraction Standards, JCPDS, in: International Centre for Diffraction Data. Powder Diffraction File-PDF-4, ICDD, (CDROM), Pennsylvania 2009. 